\title{
Association of bGH and Pit-1 gene variants with milk production traits in dairy Gyr bulls
}

\author{
Keiko Kusamura de Mattos ${ }^{(1)}$, Silvia Nassif Del Lama(1) Mario Luiz Martinez $^{(2)}$ and Ary Ferreira Freitas ${ }^{(2)}$
}

\begin{abstract}
(1)Universidade Federal de São Carlos, Dep. de Genética e Evolução, Caixa Postal 676, CEP 13565-905 São Carlos, SP, Brazil. E-mail: keikomattos@ig.com.br, dsdl@power.ufscar.br (2)Embrapa Gado de Leite, R. Eugênio de Nascimento, 610, Dom Bosco, CEP $36038-330$ Juiz de Fora, MG, Brazil. E-mail: martinez@cnpgl.embrapa.br, ary@cnpgl.embrapa.br
\end{abstract}

\begin{abstract}
The objective of this study was to obtain genetic marker information in the Gyr breed by analyzing bGH and Pit-1 gene polymorphisms and to verify their association with milk production traits. One sample including $40 \mathrm{Gyr}$ bulls were genotyped at two bGH gene restriction sites (bGH- AluI and bGH-MspI) and at one restriction site in the Pit-1 gene (Pit-1 HinfI). The bGH-MspI(-) allele was favorable for fat milk percentage. The heterozigous Pit-1 HinfI (+/-) bulls were superior for fat milk production, in relation to homozigous Pit-1 HinfI $(+/+)$. The Pit-1 and bGH genes are strong candidates in the dairy cattle QTL search, and zebuine populations are promising samples for this purpose.
\end{abstract}

Index terms: dairy cattle, genetic markers, polymorphism, zebu.

\section{Associação dos variantes dos genes bGH e Pit-1 com características de produção leiteira em touros Gir leiteiro}

\begin{abstract}
Resumo - O objetivo deste estudo foi obter informações dos marcadores genéticos na raça Gir pela análise dos polimorfismos nos genes bGH e Pit-1, e verificar suas associações com características de produção leiteira. Uma amostra de 40 touros da raça Gir foi genotipada, nos dois sítios de restrição no gene bGH (bGH-AluI e bGH-MspI) e em um sítio de restrição no gene Pit-1 (Pit-1 HinfI). O alelo bGH-MspI(-) favoreceu a porcentagem de gordura no leite. Os touros heterozigotos Pit-1 HinfI (+/-) foram superiores quanto à produção de gordura no leite, em relação aos homozigotos Pit-1 HinfI (+/+). Os genes Pit-1 e bGH são fortes candidatos à pesquisa de QTLs em raças leiteiras e populações zebuínas representam uma amostra promissora para esse propósito.
\end{abstract}

Termos para indexação: gado leiteiro, marcador genético, polimorfismo, zebu.

\section{Introduction}

The bovine growth hormone $(\mathrm{bGH})$ is a polypeptide of 191 amino acids and its role in growth, lactation, and mammary gland development has been extensively studied (Etherton \& Bauman, 1998). The galactopoietic effect of bGH can be explained by its direct involvement in many tissues and metabolism adaptation in all nutrient classes. Furthermore, in a manner thought to be mediated by the insulin-like growth factor system, it also indirectly affects the mammary gland (Bauman, 1999). The bGH gene is considered an attractive candidate gene for use as a beef and milk production marker due to its role in galactopoietic metabolism and the growth process. A considerable number of studies seeking an association between variants of this gene and productive traits has been reported (Høj et al., 1993; Lucy et al., 1993; Lagziel et al., 1996, 1999).
The pituitary transcription factor (Pit-1) is the cellspecific transcription factor for activating expression of the prolactin, thyrotropin, and GH genes in the anterior pituitary gland (Tuggle \& Trenkle, 1996). Bovine Pit-1 is a 291 amino acid protein with DNA-binding POU domain. This gene is another candidate for milk production marker because of its role in regulating expression of bGH and the prolactin genes.

The Brazilian herd composition is unique, i.e., importation of several taurine and zebuine breeds has occurred on a wide scale and consequently a great number of crossbred and synthetic breed animals has emerged. Zebuine breed populations constitute an interesting field for genetic studies since they present traits very different from those of the taurine breed.

The objective of this study was to contribute to marker gene information about the Gyr breed by analyzing bGH 
and Pit-1 gene polymorphisms and to verify their association with milk production traits.

\section{Material and Methods}

A total of $40 \mathrm{Gyr}$ sires evaluated for their genetic merit for milk fat, protein production, and milk composition based on daughter's performance were used. The animals were from the Progeny Test Programs, the National Sire Evaluation of the Dairy Gyr (Martinez et al., 1999). Predicted transmitting abilities (PTA) were estimated considering only sires having at least five daughters.

Genomic DNA from semen was prepared according to standard protocol (Zadworny \& Kuhnlein, 1990). The PCR reactions contained $100 \mathrm{ng}$ DNA, $1 \mu \mathrm{M}$ each primer, $200 \mu \mathrm{M}$ each dNTP, 1.0 unit of Taq polymerase, and PCR buffer (Tris-HCl $10 \mathrm{mM} \mathrm{pH} 8.3$ with $2.5 \mathrm{mM} \mathrm{MgCl}_{2}$, $50 \mathrm{mM} \mathrm{KCl}$, and $0.1 \mathrm{mg} / \mathrm{mL}$ of bovine serum albumin). The primer sequence used for the bGH AluI site was: $\mathrm{P}_{1}$ : GCTGCTCCTGAGGGCCCTTCG (Schlee et al., 1994a) and $\mathrm{P}_{2}$ : GCGGCGGCACTTCA TGACCCT (Schlee et al., 1994b); for the bGH MspI site, the sequence was: $P_{1}$ : AGAATGAG GCCCAGCAGAAAT (Høj et al., 1993); $\mathrm{P}_{2:}$ GCGGCG GCACTTCATGACCCT (Schlee et al., 1994b); for the Pit-1 HinfI site: $P_{1}$ : CAATGAGAAAGTTGGTGC; and $\mathrm{P}_{2}$ : TCTGCATTCGAGATGCTC (Moody et al., 1995). Amplification programs were 2 cycles of $94^{\circ} \mathrm{C}(2 \mathrm{~min})$, $62^{\circ} \mathrm{C}(1 \mathrm{~min})$, and $72^{\circ} \mathrm{C}(2 \mathrm{~min}) ; 2$ cycles of $94^{\circ} \mathrm{C}$ (1 min), $61^{\circ} \mathrm{C}(1 \mathrm{~min})$, and $72^{\circ} \mathrm{C}(2 \mathrm{~min})$, followed by 25 cycles of $94^{\circ} \mathrm{C}(45 \mathrm{sec}), 60^{\circ} \mathrm{C}(45 \mathrm{sec})$, and $72^{\circ} \mathrm{C}(45 \mathrm{sec})$ for the bGH AluI site; 5 cycles of $94^{\circ} \mathrm{C}(2 \mathrm{~min}), 60^{\circ} \mathrm{C}$ $(1 \mathrm{~min})$, and $72^{\circ} \mathrm{C}(2 \mathrm{~min})$, followed by 25 cycles of $94^{\circ} \mathrm{C}$ $(1 \mathrm{~min}), 58^{\circ} \mathrm{C}(1 \mathrm{~min})$, and $72^{\circ} \mathrm{C}(1 \mathrm{~min} 20 \mathrm{sec})$ for the bGH MspI site. For the Pit-1 HinfI site, the program described by Moody et al. (1995) was used.

The PCR product $(20 \mu \mathrm{L})$ was digested by restriction enzyme: eight units of AluI, or eight units of MspI, or 4 units of HinfI as described by the manufacturer. Following digestion, the samples were electrophoresed through a $3 \%$ low melting agarose gel.

Genetic effect of the genotypes (AluI, MspI loci of the bGH gene and HinfI locus of the Pit-1 gene) on milk and fat production was estimated using the daughter yield deviation (DYD). The DYD is the average yield of the daughter of each bull adjusted to non genetic effects (herd, year-season of calving and age at calving). It was calculated as DYD $=2 \times \mathrm{PTA} / \mathrm{REL}$, where PTA is the sire's predicted transmitting ability estimated using an animal model, and REL is the reliability of the sire's PTA. The animal model included the fixed effects of herdyear-season, age at calving and daughter's genetic composition, besides animal random effects and error. All the available pedigree information was used to generate the relationship matrix. Only first lactation was used to estimate sire's PTA.

The statistical model was:

$\mathrm{Y}_{\mathrm{ij}}=\mu+\mathrm{CG}_{\mathrm{i}}+\mathrm{e}_{\mathrm{ij}}$,

where $Y_{i j}$ is the average DYD for each trait (milk, fat production, fat percentages); $\mu$ is the effect of the general average; $\mathrm{CG}_{\mathrm{i}}$ is the fixed effect of genotype of candidate gene (AluI or MspI of bGH gene and HinfI of Pit-1 gene), and $e_{i j}$ is the random error effect. A weighted least square method was used to account for the non homogeneous variance among genotypes.

\section{Results and Discussion}

The fragment amplified for identifying MspI site polymorphism ( $858 \mathrm{bp}$ ) contained three MspI recognition sites, i.e., two monomorphics and one polymorphic. The MspI (+) phenotype was characterized after restriction enzyme digestion by four fragments $(\sim 54, \sim 93, \sim 99$ and $\sim 612 \mathrm{bp}$ ) and the MspI (-) phenotype by three fragments ( $99, \sim 54$, and $\sim 705 \mathrm{bp})$. After digestion, the AluI amplified fragment ( $223 \mathrm{bp}$ ) revealed two alleles, i.e., $\mathrm{V}$ allele, without recognition site ( $223 \mathrm{bp})$, and $\mathrm{L}$ allele, characterized by two fragments ( 171 bp and $\sim 52 \mathrm{bp})$.

As described previously by Moody et al. (1995), the Pit-1 HinfI amplified fragment ( 1,355 bp) had two monomorphics and one polymorphic HinfI recognition sites. After digestion, it resulted in two alleles, HinfI (+) and HinfI (-). The latter was identified by three fragments: $\sim 270, \sim 425$ and $\sim 660 \mathrm{bp}$; and the former, by four fragments: 270, $\sim 385, \sim 660$ and $\sim 40 \mathrm{bp}$.

The MspI (-) frequency was 0.81 (Table 1). Zebuine breed bGH MspI (-) frequencies are reported in the literature, i.e., Sahiwal, 0.86 (Mitra et al., 1995); Brazilian Nellore, 0.82; and Ongole, 1.00 (Lagziel et al., 2000). Taurine breeds, in contrast, have reported low MspI (-) allele frequencies, i.e., Holstein breed, 0.26 (Zhang et al., 1993); Angus, 0.14; Brown Carpathian of Ukraine, 0.26; Hereford, 0.00; Jersey, 0.15; Limousin, 0.39 (Lagziel et al., 2000), and Red Danish, 0.05 (Høj et al., 1993). It has been proposed that the MspI (-) allele originated in the Indian subcontinent because frequencies of this allele in relation to geographic origin of breeds shows a cline 
pattern, decreasing with distance from the Indian subcontinent (Lagziel \& Soller, 1999; Lagziel et al., 2000).

The Gyr sires were monomorphics in the AluI bGH locus, indicating either that the $\mathrm{L}$ allele is fixed in this population or that frequency may be too low to be detected (Table 1). No previous information was found about this allele in the Indian Gyr breed population. However, a frequency of 0.04 for $\mathrm{V}$ allele has been reported for the Sahiwal breed in India (Mitra et al., 1995).

Frequency of allele HinfI (-) of Pit-1 gene was 0.05 (Table 1). The value determined in the Gyr breed for the present study can be classified as low when compared with the allelic frequency range reported in the literature for Angus (0.45), Holstein (0.26), Hereford (0.21) and Brahman (0.10) (Moody et al., 1995).

Estimates of candidate gene effect on milk, fat, protein production, and fat and protein percentages, for each of the two loci (bGH MspI and Pit-1 HinfI) analyzed are presented in Table 2. The bGH AluI locus was not analyzed because it was monomorphic.

A superiority of the MspI (-) allele for fat percentage $(\mathrm{P}<0.05)$ was observed. There is no information reported about association between bGH MspI variants and fat percentage. There are reports about MspI(-) association with fat production in both Red Danish and Norwegian Red dairy cattle (Høj et al., 1993) and protein percentage in Israeli Holstein dairy cattle (Lagziel et al., 1999).

The notable bGH effect on milk production (Bauman, 1999) supports a possible direct effect of functional site polymorphism at bGH locus. A conceivable mechanism for MspI site polymorphism effect in the present study could be related to the localization of this MspI site, which

Table 1. Genotypic and allelic frequencies of bGH MspI, bGH AluI and Pit-1 HinfI variants in Gyr breed sires.

\begin{tabular}{crcc}
\hline Genotype & $\mathrm{n}$ & Genotypic frequencies & Allelic frequencies \\
\hline & \multicolumn{4}{c}{ bGH-MspI } \\
++ & 3 & 0.075 & $0.19(+)$ \\
+- & 9 & 0.225 & $0.81(-)$ \\
-- & 28 & 0.700 & $1.00(\mathrm{~L})$ \\
\hline & \multicolumn{4}{c}{ bGH-AluI } \\
LL & 39 & 1.000 & \\
LV & - & - & $0.95(+)$ \\
VV & - & - & $0.05(-)$ \\
\hline
\end{tabular}

is located in the intron III, near a transcription binding site (Parmentier et al., 1999). However, if the bGH MspI (-) allele effect is limited to the Gyr breed, it suggests a nonfunctional role of this site. One of the explanation for the results obtained is that they may be due to a linkage disequilibrium of a favorable locus and the bGH MspI (-) site. Another explanation is that a coadaptation of the MspI (-) allele to a set of zebuine genes limits its effect on fat yield to the zebuine genomic background.

The heterozygotes HinfI (+/-) sires were superior in relation to the HinfI $(+/+)$ sires for fat production $(\mathrm{P}<0.05)$. The HinfI $(-/-)$ genotype was not observed because of the low HinfI (-) allele frequency.

The Pit-1 HinfI polymorphism in the Holstein breed was investigated by Renaville et al. (1997). These researchers used fixed and mixed linear models to fit DYD and thus showed the superior effect of HinfI (-) allele on milk and protein yields, and negative effect on fat percentage. Influence of this allele on fat yield was not observed. An additional study (Parmentier et al., 1999) demonstrated significant superiority of the HinfI (-) allele for milk and protein yield, but an inferiority for fat yield.

Table 2. Daughter yield deviation (DYD) for milk, fat, protein production and fat percentage of Gyr breed sires with different bGH and Pit-1 gene genotypes.

\begin{tabular}{|c|c|c|c|c|}
\hline Trait & Genotype & Mean & Standard error & $\begin{array}{c}\text { Significance } \\
\text { level }\end{array}$ \\
\hline & & & bGH-MspI & \\
\hline \multirow[t]{3}{*}{ Milk (kg) } & ++ & 58.7 & 434.3 & \\
\hline & +- & 166.1 & 73.5 & $\mathrm{~ns}$ \\
\hline & - - & 99.7 & 55.5 & \\
\hline \multirow[t]{3}{*}{ Fat $(\mathrm{kg})$} & ++ & 2.4 & 13.2 & \\
\hline & +- & 10.4 & 3.5 & $\mathrm{~ns}$ \\
\hline & - & 7.1 & 1.9 & \\
\hline \multirow[t]{4}{*}{ Fat $(\mathrm{kg})$} & ++ & 5.6 & 3.4 & \\
\hline & +- & 1.9 & 2.0 & $\mathrm{P} \leq 0.05$ \\
\hline & - & 4.1 & 1.5 & \\
\hline & & & Pit-1-HinfI & \\
\hline \multirow[t]{3}{*}{ Milk (kg) } & ++ & 90.3 & 42.0 & \\
\hline & +- & 300.3 & 128.7 & $\mathrm{~ns}$ \\
\hline & -- & - & - & \\
\hline \multirow[t]{3}{*}{ Fat $(\mathrm{kg})$} & ++ & 6.5 & 1.7 & \\
\hline & +- & 16.6 & 4.0 & $\mathrm{P} \leq 0.05$ \\
\hline & -- & - & - & \\
\hline \multirow[t]{3}{*}{ Fat $(\mathrm{kg})$} & ++ & 2.7 & 1.2 & \\
\hline & +- & 4.6 & 13.6 & $\mathrm{~ns}$ \\
\hline & -- & - & & \\
\hline
\end{tabular}

ns No-significant. 
The results on fat yield in Gyr breed does not agree with previous results reported for the Holstein breed (Renaville et al., 1997; Parmentier et al., 1999). These differences of Pit-1 HinfI (-) allele effect between Gyr breed and that observed in Holstein sires (Renaville et al., 1997) suggest a nonfunctional role for this variant. It is possible that a linked functional locus, other than Pit-1, affecting milk production is involved, whether in tighter or looser linkage disequilibrium with Pit-1 HinfI locus. Another explanation is the existence of a different genomic background effect. The long divergence between $B$. taurus and $B$. indicus must have resulted in several genomic differences and it is certainly possible that the same variant presents different effects because of different genomic background influences.

Further studies with daughter samples from heterozygous sire can increase information concerning the molecular event underlying the somatotropic axis gene action and its effects on milk production traits.

\section{Conclusions}

1. In the Gyr breed sire population studied there are associations of the bGH-MspI and Pit-1 HinfI variants on fat percentage and fat yield, respectively.

2 . The zebuine breed population is an interesting source for QTL research because of their gene diversity and variety of the gene effect.

\section{Acknowledgements}

To Fapesp, Capes and CNPq for financial support.

\section{References}

BAUMAN, D.E. Bovine somatotropin and lactation: from basic science to commercial application. Domestic Animal Endocrinology, v.17, p.101-116, 1999.

ETHERTON, T.D.; BAUMAN, D.E. Biology of somatotropin in growth and lactation of domestic animals. Physiological Reviews, v.78, p.745-761, 1998.

HØJ, S.; FREDHOLM, M.; LARSEN, N.J.; NIELSEN, V.H. Growth hormone gene polymorphism associated with selection for milk fat production in lines of cattle. Animal Genetics, v.24, p.91-96, 1993.

LAGZIEL, A.; DENISE, S.; HANOTTE, O.; DHARA, S.; GLAZKO, V.; BROADHEAD, A.; DAVOLI, R.; RUSSO, V.; SOLLER, M. Geographic and breed distribution of an MspI PCRRFLP in the bovine growth hormone (bGH) gene. Animal Genetics, v.31, p.210-213, 2000.
LAGZIEL, A.; LIPKIN, E.; EZRA, E.; SOLLER, M.; WELLER, J.I. An MspI polymorphism at the bovine growth hormone (bGH) gene is linked to a locus affecting milk protein percentage. Animal Genetics, v.30, p.296-299, 1999.

LAGZIEL, A.; LIPKIN, E.; SOLLER, M. Association between SSPC haplotypes at the bovine growth hormone gene and milk protein percentage. Genetics, v.142, p.946-951, 1996.

LAGZIEL, A.; SOLLER, M. DNA sequence of SSCP haplotypes at the bovine growth hormone (bGH) gene. Animal Genetics, v.30, p.362-365, 1999.

LUCY, M.C.; HAUSER, S.D.; EPPARD, P.J.; KRIVI, G.G.; CLARK, J.H.; BAUMAN, D.E.; COLLIER, R.J. Variants of somatotropin in cattle: gene frequencies in major dairy breeds and associated milk production. Domestic Animal Endocrinology, v.10, p.325-333, 1993.

MARTINEZ, M.L.; VERNEQUE, R.S.; TEODORO, R.L. Programa nacional de melhoramento genético do Gir leiteiro: resultado do teste de progenie 7. Juiz de Fora: Embrapa Gado de Leite, 1999. 4p.

MITRA, A.; SCHLEE, P.; BALAKRISHNAN, C.R.; PIRCHNER, F. Polymorphisms at growth hormone and prolactin loci in Indian cattle and buffalo. Journal of Animal Breeding and Genetics, v.112, p.71-74,1995.

MOODY, D.E.; POMP, D.; BARENDSE, W. Restriction fragment length polymorphism in amplification products of the bovine PIT-1gene and assignment of PIT-1 to bovine chromosome 1. Animal Genetics, v.26, p.45-47, 1995.

PARMENTIER, I.; PORTETELLE, D.; GENGLER, N.; PRADI, A.; BERTOZZI, C.; VLEURICK,L.; GILSON, R.; RENAVILLE, R. Candidate gene markers associated with somatotropic axis and milk selection. Domestic Animal Endocrinology, v.17, p.139-148, 1999.

RENAVILLE, R.; GENGLER, N.; VRECH, E.; PRANDI, A.; MASSART, S.; CORRADINI, C.; BERTOZZI C.; MORTIAUX, F.; BURNY, A.; PORTETELLE, D. Pit-1gene polymorphism, milk yield, and conformation traits for Italian Holstein Friesian bulls. Journal of Dairy Science, v.80, p.3431-3438, 1997.

SCHLEE, P.; GRAML, R.; ROTTMANN, O.; PIRCHNER, F. Influence of growth hormone genotypes on breeding values of Simmental bulls. Journal of Animal Breeding and Genetics, v.111, p.253-256, 1994a.

SCHLEE, P.; GRAML, R.; SCHALLENBERGER, E.; SCHAMS, D.; ROTTMANN, O.; OLBRICH BLUDAU, A.; PIRCHNER F. Growth hormone and insulin like growth factor I: concentration in bulls of various growth hormone genotypes. Theoretical and Applied Genetics, v.88, p.497-500, 1994b.

TUGGLE, C.K.; TRENKLE, A. Control of growth hormone synthesis. Domestic Animal Endocrinology, v.13, p.1-33, 1996.

ZADWORNY, D.; KUHNLEIN, U. The identification of the Kappa casein genotype in Holstein dairy cattle using polimerase chain reaction. Theoretical and Applied Genetics, v.80, p.631-634, 1990.

ZHANG, H.M.; BROWN, D.R.; DENISE, S.K.; AX, R.L. Polymerase chain reaction restriction fragment length polymorphism analysis of the bovine somatotropin gene. Journal of Animal Science, v.71, p.2276, 1993.

Received on May 7, 2003 and accepted on November 27, 2003 